\title{
Penerapan Datamining Asosiasi Pada Sistem Persediaan Kosmetik (Kasus Toko Atom Cosmetic Pematangsiantar)
}

\author{
Dinda Zhila Azhari ${ }^{1}$, Sinta Dwi Hastuti ${ }^{2}$ \\ Program studi Sistem Informasi, STIKOM Tunas Bangsa \\ dindazhilaazhari@gmail.com ${ }^{1}$, sintadwihastuti28@gmail.com ${ }^{2}$
}

\begin{abstract}
The purpose of this research is to find out whether the aamination method with the a priori method can be applied to the cosmetics inventory system at toko atom cosmetic pematangsiantar. The data is sourced from toko atom cosmetic pematangsiantar by conducting interviews with owners and analyzing several sales transactions over the past 1 months. The results of the application of a priori algorithms to the Datamining technique are very efficient and can accelerate the process of forming the pattern pattern of the combination of items from the sale of cosmetic products in the atomic cosmetics store Pematangsiantar, namely with the highest support and confidence are Bedak Wardah - Wardah Foundation and Wardah Foundation - You BB Coushion.
\end{abstract}

Keywords: Datamining, Cosmetics, a priori, Inventory, Pematangsiantar

\begin{abstract}
Abstrak
Tujuan dari penelitian ini adalah untuk mengetahui apakah metode datamining dengan metode apriori dapat diterapkan pada sistem persediaan kosmetik di toko atom cosmetic pematangsiantar. Data bersumber dari toko atom cosmetic pematangsiantar dengan melakukan wawancara terhadap pemilik dan menganalisa beberpa transaksi penjualan selama 1 bulan terakhir. Hasil dari penerapan algoritma apriori pada teknik Datamining sangat efisien dan dapat mempercepat proses pembentukan kecenderungan pola kombinasi itemset hasil penjualan produk kosmetik di toko atom cosmetic Pematangsiantar, yaitu dengan support dan confidence tertinggi adalah Bedak Wardah Wardah Foundation dan Wardah Foundation - You BB Coushion.
\end{abstract}

Kata Kunci: Datamining, Kosmetik, Apriori, Persediaan

\section{Pendahuluan}

Algoritma apriori pada saat ini telah diimplementasikan keberbagai bidang, salah satunya adalah dibidang bisnis atau perdangangan dan bidang pendidikan, dibidang bisnis misalnya implementasi data mining algoritma apriori untuk sistem penjualan tujuanya untuk membantu para pembisnis meningkatkan penjualan produk, Sedangkan dibidang pendidikan misalnya implementasi data mining untuk menemukan pola hubungan tingkat kelulusan mahasiswa dengan data induk mahasiswa. Adanya kegiatan operasional sehari-hari data semakin lama akan semakin bertambah banyak. Jika dibiarkan saja, maka data-data transaksi tersebut hanya menjadi sampah yang tidak berarti. Dengan adanya dukungan perkembangan teknologi, semakin berkembang pula kemampuan dalam mengumpulkan dan mengolah data.

Persaingan di dunia bisnis, khususnya dalam industri toko kosmetik, menuntut para pengembang untuk menemukan suatu strategi yang dapat meningkatkan penjualan khusus penjualan kosmetik dengan memaksimalkan pelayanan kepada konsumen. Salah satu caranya adalah dengan tetap tersediaannya berbagai jenis kosmetik ditoko kosmetik. Untuk mengetahui kosmetik apa saja yang dibeli oleh para konsumen, dapat dilakukan dengan menggunakan teknik analisis keranjang 
pasar yaitu analisis dari kebiasaan membeli konsumen. Cabang ilmu komputer tersebut adalah Artificial Intelligence seperti datamining [1]-[7], Sistem Pendukung Keputusan [8]-[21], sistem pakar [22], Jaringan Saraf Tiruan [23]-[26][27], [28], logika fuzzy [29] dan lain-lain. Salah satu ilmu computer yang dapat diterapkan dalam menyelesaikan permasalahan di atas adalah teknik datamining dengan metode klastering [30]. Penelitian ini mengunakan pendeteksian mengenai kosmetik yang sering terbeli secara bersamaan yang disebut association rule (aturan asosiasi). Proses pencarian asosiasi atau hubungan antar item data ini diambil dari suatu basis data relasional. Proses tersebut menggunakan algoritma apriori.

\section{Metodologi Penelitian}

\subsection{Datamining}

Hal penting yang terkait dengan data mining adalah:

1. Data mining merupakan suatu proses otomatis terhadap data yang sudah ada.

2. Data yang akan diproses berupa data yang sangat besar.

3. Tujuan data mining adalah mendapatkan hubungan atau pola yang akan mungkin memberikan indikasi yang bermanfaat [31].

Berikut adalah flowchat dari K-means yang merupakan bagian dari datamining klastering seperti yang ditunjukkan pada gambar berikut:

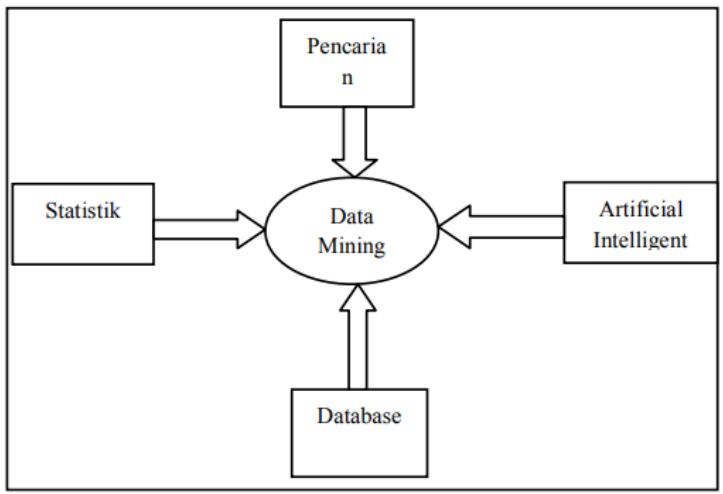

Gambar 1. Bidang Ilmu Data Mining

\subsection{Asosiasi}

Aturan asosiasi menggunakan data latihan, sesuai dengan pengertian data mining, untuk menghasilkan pengetahuan. Pengetahuan untuk mengetahui item-item belanja yang sering dibeli secara bersamaan dalam suatu waktu. Aturan asosiasi yang berbentuk "if...then..." atau "jika...maka..." merupakan pengetahuan yang dihasilkan dari fungsi Aturan Asosiasi [4].

\subsection{Metode Apriori}

Analisis asosiasi dikenal juga sebagai salah satu teknik data mining yang menjadi dasar dari berbagai teknik data mining lainya, khususnya salah satu tahap dari analisis asosiasi yang disebut analisis pola frekuensi tinggi (frequent pattern mining) [6].

Berikut langkah - langkah di dalam kerangka pemikiran tersebut dapat di gambarkan dalam bentuk flowchart berikut ini: 


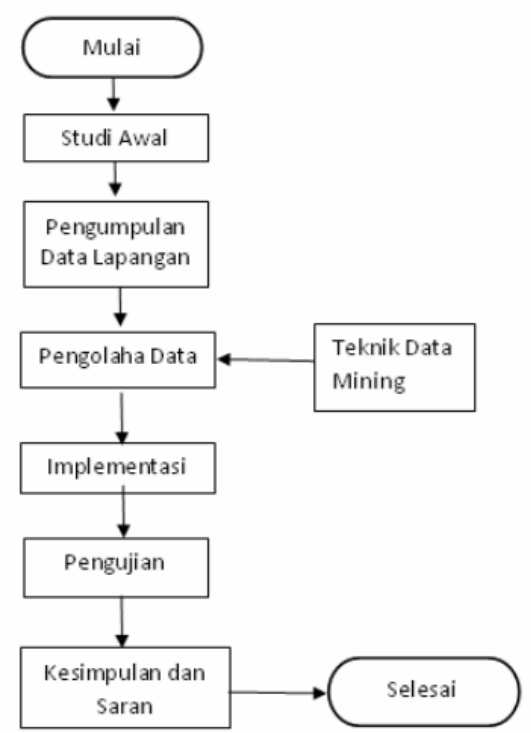

Gambar 2. Flowchart penelitian

\section{Hasil dan Pembahasan}

Berikit adalah data transaksi toko kosmetik atom pematangsiantar seperti yang ditunjukkan pad atabel berikut:

Tabel 1. Data Penjualan

\begin{tabular}{|c|c|c|}
\hline No & No Faktur & Nama Barang \\
\hline \multirow[t]{3}{*}{1} & \multirow[t]{3}{*}{ 26-11-19-041 } & Bedak Wardah \\
\hline & & Wardah Foundation \\
\hline & & Inez Conceling Stick \\
\hline \multirow[t]{4}{*}{2} & \multirow[t]{4}{*}{ 16-11-19-042 } & Maybelline Mascara Series \\
\hline & & Mustika Ratu Zaitun Body Butter \\
\hline & & Maybelline Fitt me! Concealer \\
\hline & & Make Over Sparkling White \\
\hline \multirow[t]{3}{*}{3} & \multirow[t]{3}{*}{$16-11-19-043$} & Bedak Wardah \\
\hline & & Maybelline Instant Pore Eraser \\
\hline & & Make Over Ulta Cover Liquid Matt Foundation \\
\hline \multirow[t]{4}{*}{4} & \multirow[t]{4}{*}{ 16-11-19-044 } & You BB Coushion \\
\hline & & You Longlasting Ultra Waterproof Eyeliner \\
\hline & & Maybelline Fitt me! Concealer \\
\hline & & Make Over Sparkling Powder \\
\hline \multirow[t]{4}{*}{5} & \multirow[t]{4}{*}{ 16-11-19-045 } & You Longlasting Ultra Waterproof Eyeliner \\
\hline & & Wardah Foundation \\
\hline & & Pixy Make it Glow Dewy Coushion \\
\hline & & Make Over Ulta Cover Liquid Matt Foundation \\
\hline \multirow[t]{3}{*}{6} & \multirow[t]{3}{*}{ 16-11-19-046 } & Mustika Ratu Air Suci Mawar Putih \\
\hline & & Wardah Foundation \\
\hline & & Mustika Ratu Zaitun Body Butter \\
\hline \multirow[t]{2}{*}{7} & \multirow[t]{2}{*}{$16-11-19-047$} & Make Over Sparkling Powder \\
\hline & & Maybelline Mascara Series \\
\hline \multirow[t]{3}{*}{8} & \multirow[t]{3}{*}{$16-11-19-048$} & Satto C Cream \\
\hline & & Make Over Sparkling Powder \\
\hline & & Loreal True Match Blush Cream \\
\hline \multirow[t]{3}{*}{9} & \multirow[t]{3}{*}{ 16-11-19-049 } & Bedak Wardah \\
\hline & & Wardah Foundation \\
\hline & & Pond's Men Pollution Out fc \\
\hline \multirow[t]{3}{*}{10} & \multirow[t]{3}{*}{ 16-11-19-050 } & Make Over Sparkling Powder \\
\hline & & Viva Face Powder \\
\hline & & You BB Coushion \\
\hline
\end{tabular}




\begin{tabular}{|c|c|c|}
\hline No & No Faktur & Nama Barang \\
\hline \multirow{3}{*}{11} & \multirow{3}{*}{$16-11-19-051$} & M2J Aloe Vera \\
\hline & & Wardah Lightening Series \\
\hline & & Viva Face Powder \\
\hline \multirow[t]{3}{*}{12} & \multirow[t]{3}{*}{ 16-11-19-052 } & Bedak Wardah \\
\hline & & Pond's Men Pollution Out fc \\
\hline & & Wardah Foundation \\
\hline \multirow[t]{3}{*}{13} & \multirow[t]{3}{*}{$16-11-19-053$} & Garnier Sakura Ultimate Serum \\
\hline & & Pond's Men Pollution Out fc \\
\hline & & Maybelline Mascara Series \\
\hline \multirow[t]{2}{*}{14} & \multirow[t]{2}{*}{ 16-11-19-054 } & Viva Milk Body Mask \\
\hline & & You BB Coushion \\
\hline \multirow[t]{3}{*}{15} & \multirow[t]{3}{*}{ 16-11-19-055 } & Maybelline Fitt me! Concealer \\
\hline & & Viva Milk Body Mask \\
\hline & & Make Over Ulta Cover Liquid Matt Foundation \\
\hline \multirow[t]{2}{*}{16} & \multirow[t]{2}{*}{$16-11-19-056$} & Pixy Make it Glow Dewy Coushion \\
\hline & & Viva Face Powder \\
\hline \multirow[t]{4}{*}{17} & \multirow[t]{4}{*}{$16-11-19-057$} & Viva Milk Body Mask \\
\hline & & You BB Coushion \\
\hline & & Olay Total Effect Day Cream spf 15 \\
\hline & & Wardah Lightening Series \\
\hline \multirow[t]{3}{*}{18} & \multirow[t]{3}{*}{ 16-11-19-058 } & Viva Face Tonic \\
\hline & & Maybelline Fitt me! Concealer \\
\hline & & Olay White Radiance \\
\hline \multirow[t]{3}{*}{19} & \multirow[t]{3}{*}{$16-11-19-059$} & Olay White Radiance \\
\hline & & Wardah Foundation \\
\hline & & You BB Coushion \\
\hline \multirow[t]{3}{*}{20} & \multirow{3}{*}{ 16-11-19-060 } & Ponds Age Miracle Day Cream \\
\hline & & Maybelline Mascara Series \\
\hline & & Ponds Acne Solution Facial Gel \\
\hline \multirow[t]{3}{*}{21} & \multirow[t]{3}{*}{ 16-11-19-061 } & Garnier Sakura Night Cream \\
\hline & & Wardah Foundation \\
\hline & & Ponds Acne Solution Facial Gel \\
\hline \multirow[t]{4}{*}{22} & \multirow[t]{4}{*}{$16-11-19-062$} & Make Over Ulta Cover Liquid Matt Foundation \\
\hline & & Ponds Age Miracle Day Cream \\
\hline & & Pixy UV Whitening BB Cream \\
\hline & & Wardah Lightening Series \\
\hline 23 & $16-11-19-063$ & Bedak Wardah \\
\hline & & Pixy UV Whitening BB Cream \\
\hline & & Pixy Make it Glow Dewy Coushion \\
\hline & & Ponds Age Miracle Day Cream \\
\hline & & Wardah Foundation \\
\hline 24 & $16-11-19-064$ & Make Over Intense Matte Lip Cream \\
\hline & & Wardah Lightening Series \\
\hline & & Make Over Intense Matte Lip Cream \\
\hline 25 & $16-11-19-065$ & Maybelline Mascara Series \\
\hline & & Make Over Ulta Cover Liquid Matt Fo \\
\hline
\end{tabular}

Sumber: toko kosmetik atom pematangsiantar

Berdasarkan tabel 1, dapat dilakukan pembentukan Item yang merupakan penyelesaian berdasarkan data yang tersedia pada transaksi penjualan di toko Atom Pematangsiantar dengan menggunakan formula:

Rumus : $\quad$ Support $(\mathrm{A})=$

Jumlah_Transaksi_Yang_Mengandung_A

$\sum$ Transaksi 
Tabel 2. Data Support Dari Setiap Item

\begin{tabular}{clcc}
\hline No & \multicolumn{1}{c}{ Nama Item } & Support & Support (\%) \\
\hline 1 & Bedak Wardah & 5 & $20 \%$ \\
2 & Inez Conceling Stick & 1 & $4 \%$ \\
3 & Wardah Foundation & 8 & $32 \%$ \\
4 & Mustika Ratu Zaitun Body Butter & 2 & $8 \%$ \\
5 & You BB Coushion & 5 & $20 \%$ \\
6 & Make Over Sparkling White & 1 & $4 \%$ \\
7 & Maybelline Instant Pore Eraser & 1 & $4 \%$ \\
8 & Make Over Ulta Cover Liquid Matt Foundation & 5 & $20 \%$ \\
9 & You Longlasting Ultra Waterproof Eyeliner & 2 & $8 \%$ \\
10 & Maybelline Fitt me! Concealer & 4 & $16 \%$ \\
11 & Pixy Make it Glow Dewy Coushion & 3 & $12 \%$ \\
12 & Make Over Intense Matte Lip Cream & 2 & $8 \%$ \\
13 & Maybelline Mascara Series & 5 & $20 \%$ \\
14 & Mustika Ratu Air Suci Mawar Putih & 1 & $4 \%$ \\
15 & Ponds Age Miracle Day Cream & 3 & $12 \%$ \\
16 & Satto C Cream & 1 & $4 \%$ \\
17 & Wardah Lightening Series & 4 & $16 \%$ \\
18 & Viva Face Powder & 3 & $12 \%$ \\
19 & Viva Milk Body Mask & 3 & $12 \%$ \\
20 & Loreal True Match Blush Cream & 1 & $4 \%$ \\
21 & Pond's Men Pollution Out fc & 3 & $12 \%$ \\
22 & Make Over Sparkling Powder & 4 & $16 \%$ \\
23 & M2J Aloe Vera & 1 & $4 \%$ \\
24 & Garnier Sakura Ultimate Serum & 1 & $4 \%$ \\
25 & Pixy UV Whitening BB Cream & 2 & $8 \%$ \\
26 & Olay Total Effect Day Cream spf 15 & 1 & $4 \%$ \\
27 & Olay White Radiance & 2 & $8 \%$ \\
28 & Viva Face Tonic & 1 & $4 \%$ \\
29 & Ponds Acne Solution Facial Gel & 2 & $8 \%$ \\
30 & Garnier Sakura Night Cream & 1 & $4 \%$ \\
\hline & & &
\end{tabular}

Berdasarkan tabel 2, lakukan kombinasi 2 yang di dapat dari jumlah item dengan nilai support yang tertinggi seperti yang ditunjukkan pada tabel berikut:

Tabel 3. Data Support 2 Item

\begin{tabular}{clcc}
\hline No & \multicolumn{1}{c}{ Nama Item } & Support & Support (\%) \\
\hline 1 & Bedak Wardah & 5 & $20 \%$ \\
2 & Wardah Foundation & 8 & $32 \%$ \\
3 & You BB Coushion & 5 & $20 \%$ \\
4 & Make Over Ulta Cover Liquid Matt Foundation & 5 & $20 \%$ \\
5 & Maybelline Fitt me! Concealer & 4 & $16 \%$ \\
6 & Maybelline Mascara Series & 5 & $20 \%$ \\
7 & Wardah Lightening Series & 4 & $16 \%$ \\
8 & Make Over Sparkling Powder & 4 & $16 \%$ \\
\hline
\end{tabular}

Lakukan pembentukan aturan asosiasi yang ditemukan setelah nilai memenuhi sarat minimum untuk confidence dengan menggunakan formula berikut:

Confidence $=\mathrm{P}(\mathrm{B} \backslash \mathrm{A})$

SJumlah_transaksi_yang_mengandung_A_dan_B

$\sum$ Transaksi_yang_mengandung_A

Tabel 5. Data Calon Aturan Asosiasi

\begin{tabular}{clcc}
\hline No & \multicolumn{1}{c}{ Kombinasi Item (merek) } & \multicolumn{2}{c}{ Cofidence } \\
\hline 1 & $\begin{array}{l}\text { Jika membeli Bedak Wardah, maka akan membeli Wardah } \\
\text { Foundation }\end{array}$ & $4 / 5$ & $80 \%$ \\
2 & $\begin{array}{l}\text { Jika membeli Wardah Foundation, maka akan membeli } \\
\text { Bedak Wardah }\end{array}$ & $4 / 8$ & $50 \%$ \\
3 & Jika membeli Wardah Foundation, maka akan membeli You & $4 / 8$ & $50 \%$ \\
\hline
\end{tabular}




\begin{tabular}{clcc}
\hline No & \multicolumn{1}{c}{ Kombinasi Item (merek) } & \multicolumn{1}{c}{ Cofidence } \\
\hline 4 & $\begin{array}{l}\text { BB Coushion } \\
\text { Jika membeli You BB Coushion, maka akan membeli } \\
\text { Wardah Foundation }\end{array}$ & $4 / 5$ & $80 \%$ \\
\hline
\end{tabular}

Table 6. Daftar Aturan Asosiasi yang terbentuk

\begin{tabular}{clcc}
\hline No & \multicolumn{1}{c}{ Kombinasi Item (merek) } & Support & Cofidence \\
\hline 1 & $\begin{array}{l}\text { Jika membeli Bedak Wardah, maka akan membeli } \\
\text { Wardah Foundation }\end{array}$ & $16 \%$ & $80 \%$ \\
& $\begin{array}{l}\text { Jika membeli You BB Coushion, maka akan membeli } \\
\text { Wardah Foundation }\end{array}$ & $16 \%$ & $80 \%$ \\
\hline
\end{tabular}

Penelitian ini juga menggunakan batuan software untuk dengan aplikasi Tanagra 1.4 yang ditunjukkan pada gambar berikut:

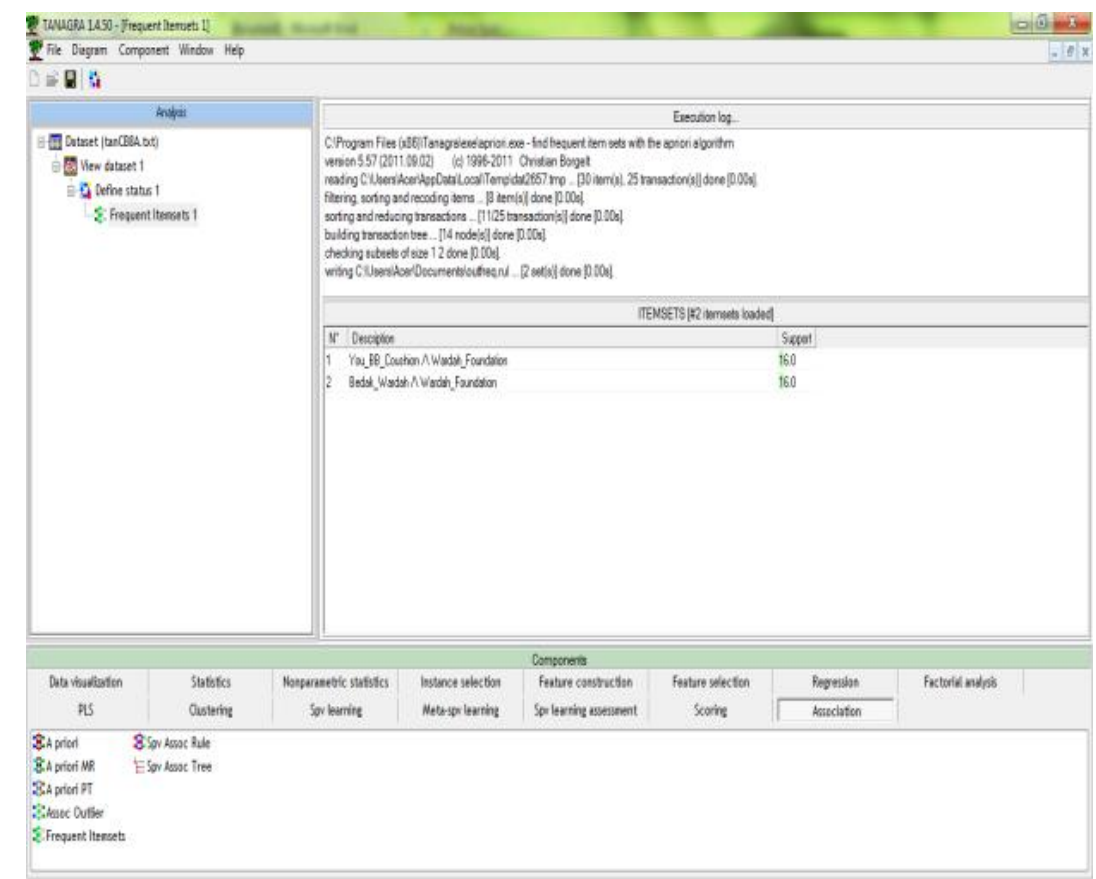

Gambar 3. Hasil Pengujian dengan Satu item dan Pola Kombinasi dua itemsets

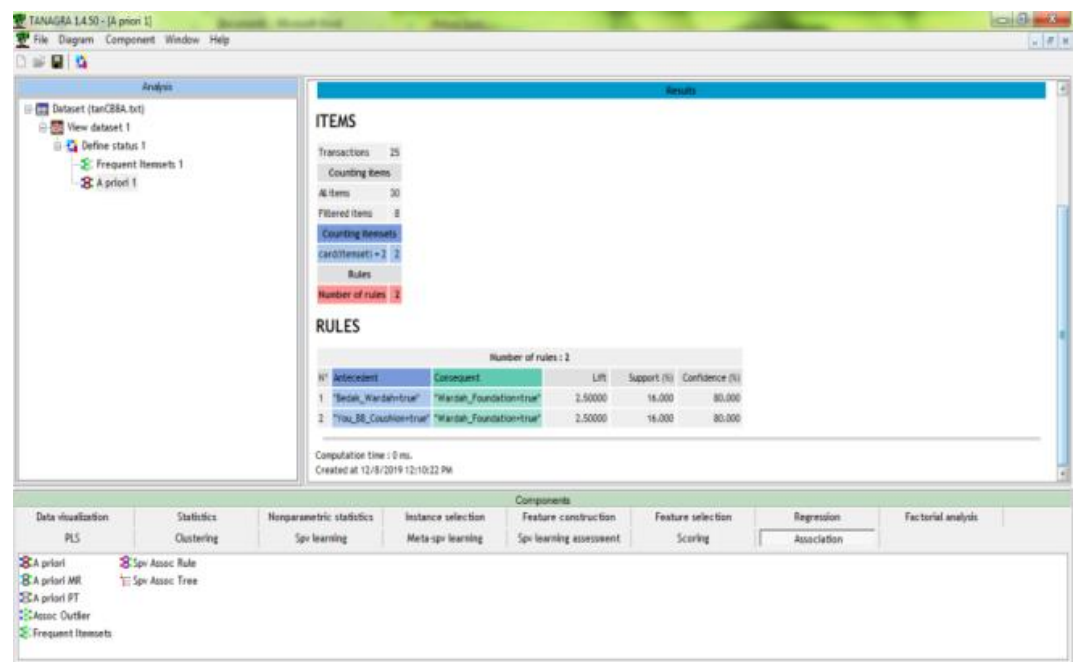

Gambar 4. Pengujian dengan rules dari pola kombinasi dua itemsets 


\section{Kesimpulan}

Berdasarkan pembahasan yang telah dilakukan dengan algoritma Apriori dan dilakukannya pengujian dengan aplikasi Tanagra maka beberapa kesimpulan yang diperoleh:

a. Data Mining dapat di implementasikan dengan menggunakan Database penjualan produk kosmetik karena dapat menemukan kecenderungan pola kombinasi itemsets sehingga dapat dijadikan sebagai informasi yang sangat berharga dalam pengambilan keputusan untuk mempersiapkan stok jenis barang apa yang diperlukan kemudian.

b. Penerapan Algoritma Apriori pada teknik Data Mining sangat efisien dan dapat mempercepat proses pembentukan kecenderungan pola kombinasi itemset hasil penjualan produk kosmetik di took atom cosmetic Pematangsiantar, yaitu dengan support dan confidence tertinggi adalah Bedak Wardah - Wardah Foundation dan Wardah Foundation - You BB Coushion.

\section{Daftar Pustaka}

[1] W. Katrina, H. J. Damanik, F. Parhusip, D. Hartama, A. P. Windarto, and A. Wanto, "C.45 Classification Rules Model for Determining Students Level of Understanding of the Subject," J. Phys. Conf. Ser., vol. 1255, no. 12005, pp. 1-7, 2019, doi: 10.1088/1742-6596/1255/1/012005.

[2] M. Widyastuti, A. G. Fepdiani Simanjuntak, D. Hartama, A. P. Windarto, and A. Wanto, "Classification Model C.45 on Determining the Quality of Custumer Service in Bank BTN Pematangsiantar Branch," J. Phys. Conf. Ser., vol. 1255, no. 12002, pp. 1-6, 2019, doi: 10.1088/1742-6596/1255/1/012002.

[3] Sudirman, A. P. Windarto, and A. Wanto, "Data mining tools | rapidminer: Kmeans method on clustering of rice crops by province as efforts to stabilize food crops in Indonesia," IOP Conf. Ser. Mater. Sci. Eng., vol. 420, no. 1, 2018, doi: 10.1088/1757-899X/420/1/012089.

[4] R. W. Sari, A. Wanto, and A. P. Windarto, "Implementasi Rapidminer Dengan Metode K-Means (Study Kasus: Imunisasi Campak Pada Balita Berdasarkan Provinsi)," KOMIK (Konferensi Nas. Teknol. Inf. dan Komputer), vol. 2, no. 1, pp. 224-230, 2018, doi: 10.30865/komik.v2i1.930.

[5] N. Rofiqo, A. P. Windarto, and D. Hartama, "Penerapan Clustering Pada Penduduk Yang Mempunyai Keluhan Kesehatan Dengan Datamining K-Means," KOMIK (Konferensi Nas. Teknol. Inf. dan Komputer), vol. 2, no. 1, pp. 216-223, 2018, doi: 10.30865/komik.v2i1.929.

[6] M. G. Sadewo, A. P. Windarto, and A. Wanto, "Penerapan Algoritma Clustering Dalam Mengelompokkan Banyaknya Desa/Kelurahan Menurut Upaya Antisipasi/ Mitigasi Bencana Alam Menurut Provinsi Dengan K-Means," KOMIK (Konferensi Nas. Teknol. Inf. dan Komputer), vol. 2, no. 1, pp. 311-319, 2018, doi: 10.30865/komik.v2i1.943.

[7] D. Hartama, A. Perdana Windarto, and A. Wanto, "The Application of Data Mining in Determining Patterns of Interest of High School Graduates," J. Phys. Conf. Ser., vol. 1339, no. 1, 2019, doi: 10.1088/1742-6596/1339/1/012042.

[8] D. R. Sari, N. Rofiqo, D. Hartama, A. P. Windarto, and A. Wanto, "Analysis of the Factors Causing Lazy Students to Study Using the ELECTRE II Algorithm," $J$. Phys. Conf. Ser., vol. 1255, no. 1, 2019, doi: 10.1088/1742-6596/1255/1/012007.

[9] R. W. Sari, A. P. Windarto, S. P. Keputusan, P. Kreatifitas, M. Pkm, and A. D. A. N. Pembahasan, "Penerapan Electree Pada Seleksi Proposal Program Kreativitas Mahasiswa ( PKM ) di STIKOM Tunas Bangsa," in Seminar Nasional Teknologi Komputer \& Sains (SAINTEKS) SAINTEKS 2019, 2019, pp. 800-806.

[10] F. Syahputra, M. Mesran, I. Lubis, and A. P. Windarto, "Sistem Pendukung 
Keputusan Pemilihan Guru Berprestasi Kota Medan Menerapkan Metode Preferences Selection Index (Studi Kasus: Dinas Pendidikan Kota Medan)," KOMIK (Konferensi Nas. Teknol. Inf. dan Komputer), vol. 2, no. 1, pp. 147-155, 2018, doi: 10.30865/komik.v2i1.921.

[11] P. P. P. A. N. W. F. I. R. H. Zer, Masitha, A. P. Windarto, and A. Wanto, "Analysis of the ELECTRE Method on the Selection of Student Creativity Program Proposals," J. Phys. Conf. Ser., vol. 1255, no. 1, 2019, doi: 10.1088/1742-6596/1255/1/012011.

[12] P. P. P. A. N. W. F. I. R. H. Zer, D. Hartama, and A. P. Windarto, "Analisis Komparasi Metode AHP dan TOPSIS dalam Pemilihan Asuransi Kategori Kesehatan Terbaik PT . Prudential," in Seminar Nasional Sains \& Teknologi Informasi (SENSASI) SENSASI 2019, 2018, pp. 427-432.

[13] M. Widyastuti, F. R. S. Samosir, A. P. Windarto, and D. Hartama, "Implementasi Metode Promethee Dalam Pemilihan Kenaikan Jabatan Sous Chef Menjadi Chef," Teknol. Komput. Sains, vol. 1, no. 1, pp. 807-812, 2019.

[14] S. Sundari, Karmila, M. N. Fadli, D. Hartama, A. P. Windarto, and A. Wanto, "Decision Support System on Selection of Lecturer Research Grant Proposals using Preferences Selection Index,” J. Phys. Conf. Ser., vol. 1255, no. 1, pp. 1-8, 2019, doi: 10.1088/1742-6596/1255/1/012006.

[15] P. Alkhairi, L. P. Purba, A. Eryzha, A. P. Windarto, and A. Wanto, "The Analysis of the ELECTREE II Algorithm in Determining the Doubts of the Community Doing Business Online," J. Phys. Conf. Ser., vol. 1255, no. 1, 2019, doi: 10.1088/1742-6596/1255/1/012010.

[16] D. N. Batubara, D. R. Sitorus P, and A. P. Windarto, "Penerapan Metode PROMETHEE II Pada Pemilihan Situs Travel Berdasarkan Konsumen," J. Sisfokom (Sistem Inf. dan Komputer), vol. 8, no. 1, pp. 46-52, 2019, doi: 10.32736/sisfokom.v8i1.598.

[17] K. Fatmawati et al., "Analysis of Promothee II Method in the Selection of the Best Formula for Infants under Three Years," J. Phys. Conf. Ser., vol. 1255, no. 1, 2019, doi: 10.1088/1742-6596/1255/1/012009.

[18] T. Imandasari, A. P. Windarto, and D. Hartama, "Seminar Nasional Teknologi Komputer \&amp; Sains (SAINTEKS) Analisis Metode MAUT Pada Pemilihan Deodorant," in Seminar Nasional Teknologi Komputer \& Sains (SAINTEKS) SAINTEKS 2019, 2019, pp. 736-739.

[19] K. F. Irnanda, F. N. Arifah, M. R. Raharjo, A. Arifin, and A. P. Windarto, "The selection of Calcium Milk Products that are appropriate for advanced age using PROMETHEE II Algorithm," J. Phys. Conf. Ser., vol. 1381, no. 1, 2019, doi: 10.1088/1742-6596/1381/1/012070.

[20] T. Imandasari, M. G. Sadewo, A. P. Windarto, A. Wanto, H. O. Lingga Wijaya, and R. Kurniawan, "Analysis of the Selection Factor of Online Transportation in the VIKOR Method in Pematangsiantar City," J. Phys. Conf. Ser., vol. 1255, no. 12008, pp. 1-7, 2019, doi: 10.1088/1742-6596/1255/1/012008.

[21] T. Imandasari and A. P. Windarto, "Penerapan Metode VIKOR Pada Pemilihan Popok Bayi Berdasarkan Jenis Kulit," Semin. Nas. Sains Teknol. Inf., pp. 215-220, 2018.

[22] Hamdani, "Sistem Pakar Untuk Diagnosa Penyakit Mata Pada Manusia," vol. 5, no. 2, pp. 13-21, 2010.

[23] A. P. Windarto, M. R. Lubis, and Solikhun, "Implementasi Jst Pada Prediksi Total Laba Rugi Komprehensif Bank Umum Konvensional Dengan Backpropagation," J. Teknol. Inf. dan Ilmu Komput., vol. 5, no. 4, pp. 411-418, 2018, doi: 10.25126/jtiik.201854767.

[24] A. P. Windarto, M. R. Lubis, and Solikhun, "Model Arsitektur Neural Network 
Dengan Backpropogation Pada Prediksi Total Laba Rugi Komprehensif Bank Umum Konvensional," Kumpul. J. Ilmu Komput., vol. 5, no. 2, pp. 147-158, 2018.

[25] A. P. Windarto, L. S. Dewi, and D. Hartama, "Implementation of Artificial Intelligence in Predicting the Value of Indonesian Oil and Gas Exports With BP Algorithm," Int. J. Recent Trends Eng. Res., vol. 3, no. 10, pp. 1-12, 2017, doi: 10.23883/IJRTER.2017.3482.J5BBS.

[26] Sumijan, A. P. Windarto, A. Muhammad, and Budiharjo, "Implementation of Neural Networks in Predicting the Understanding Level of Students Subject," Int. J. Softw. Eng. Its Appl., vol. 10, no. 10, pp. 189-204, 2016.

[27] Budiharjo, T. Soemartono, A. P. Windarto, and T. Herawan, "Predicting tuition fee payment problem using backpropagation neural network model," Int. J. Adv. Sci. Technol., vol. 120, pp. 85-96, 2018, doi: 10.14257/ijast.2018.120.07.

[28] Budiharjo, T. Soemartono, A. P. Windarto, and T. Herawan, "Predicting School Participation in Indonesia using Back-Propagation Algorithm Model," Int. J. Control Autom., vol. 11, no. 11, pp. 57-68, 2018.

[29] C. C. Lee, "Fuzzy Logic in Control Systems : Fuzzy," no. 2, 1990.

[30] D. N. Batubara, A. P. Windarto, D. Hartama, and H. Satria, "Analisis Metode KMEANS Pada Pengelompokan Keberadaan Area Resapan Air Menurut Provinsi," no. x, pp. 345-349, 2019.

[31] Cooper, “No 主観的健康感を中心とした在宅高齢者における 健康関連指標 に関する共分散構造分析Title,” pp. 5-10, 2019. 